\title{
Ecological Justica of Family Education in Javanesse Traditional Houses
}

\author{
Nur Said ${ }^{1}$, Farida Ulyani ${ }^{2}$ \\ \{nursaid@iainkudus.ac.id ${ }^{1}$, faridaulyani@iainkudus.ac.id ${ }^{2}$ \} \\ Institut Agama Islam Negeri Kudus, Indonesia ${ }^{1,2}$
}

\begin{abstract}
The house is the most familiar space in family life. The house is also a reflection of the system of ideas and worldviews in smallest community, but it has a big impact in the nation. This paper discusses the ecological justice in term of interwoven meaning in the dynamics of the structure of the symbolic space in the construction of a traditional Javanese traditional house, Kudus. We use a cultural semiotic approach in symbolic, paradigmatic and syntagmatic relations to be able to capture the fabric of meaning in cultural communication between family members both internally and externally. We conclude that in the construction of the traditional Javanese house of Kudus there is a relation of spatial structure and meaningful symbols both in ornaments, plants, and forms of decoration that reflect child-friendly family communication within the pillars of Islam. This can be observed starting from the five traps in the foundation, supporting poles, ornaments and decorations in various spaces and also in the visualization of the roof and prominent tiles. This profound message shows that the values of environmental justice in the awareness of the meaning of the Javanese are imbued with harmonious communication in relations with God, humans and their environment.
\end{abstract}

Keywords: ecological justice, cultural communication, traditional house, Java

\section{Introduction}

It is so sad and yet heartbreaking to know that different cases of child abuse have appeared in various media. Not to mention, hundred or even thousand cases of abuse and violence against children that occurred in various areas that have not been revealed yet by the media. However, this phenomenon could not be separated from the social institutions that develop in various social unit for a means of socialization and healthy social interaction based on ecological justice or vice versa.

Started from the smallest social unit; home. In Javanese, it is called omah. It does not simply serve as a physicall building for a shelter from the heat and cold where a couple live together. Javanese describe home as a part of life concept, in which, from there, they actualize themselves personally and socially (Said, 2012: 1; Tjahjono, 2000: vii). At home, another 
social unit called family functions and roles to earn a better living attained with happiness in the world and hereafter through the process of socialization.

According to Zanden as quoted by Soe'oed (1999: 30) socialization is the process of social interaction which deal with the way of thinking, feeling and behaving in order to play an effective role in the society. In culture strategy of the house role, it is called as the process of cultural apprenticeship (Said, 2012: 2).

Therefore, constructing a house in Javanese tradition requires physical and mental maturity that procession efforts, among others, is indicated by a ritual as a form of social consciousness and transcendental either by the married men and women together in attempt to achieve harmony both physically and mentally.

Even the self and mutual space are embodied one another. Spatially identifying themselves, either individually or collectively, to give birth to dwell concept that will allow someone to be the part of an environment in defining the perimeters (Schulz, 1985: 5-6). From that concept, we can understand the concept of life, the tradition to philosophy to carry out roles and functions of humans as social beings included in gender relations as well as individuals who have a belief in The Almighty.

Therefore, this paper will try to reinvent the ecological justice in the construction of Kudus traditional house as part of Javanese traditional house which then can be used as the foundation for the management of socio-friendly housing.

\section{Methodology}

This research combining poststructuralist and interpretive approaches. Poststructuralist approach emphasizes on the discovery of meaning which is not limited to text, word, or a specific sentence, but also through how the relationship between the text and the relationship between cultural sign (Baker, 2005: 19). Meanwhile, interpretive approach treats culture as a system of meaning. The fundamental assumption of this approach, culture need to be understood semiotically; as a web of significance or fabrics of meaning or patterns of meaning embodied in symbols, so that the analysis of the culture must, necessarily, be interpretive (hermeneutic) to explore the meaning (Geertz, 1973: 5).

Cultural phenomenon in this case is seen as a sign of a significant phenomenon that can be approached through two sides; as a system of signs as well as the signifiying practices (Eco, 1979: 61). Semiotics in this case can be a form of deconstruction of the current understandings that has been considered thoroughly so as to be able to open up to new possibilities (Barthes, 1967).

For the data collection, the writers use direct observation technique, in-depth interviews and documentation which were implemented according to the nature and the need of data. The data gathered, then, was analyzed through post-structuralist approach and supported with semiotic approach, to understand how the interaction of symbolic structure of spatial artifacts in Kudus traditional house play the power mechanism role in giving ekspresive and normative bolster that raise the ethical and aesthetic awareness in living. 


\section{Results and Discussion}

\subsection{The house as a medium of cultural communication}

The relation between house and "to dwell" concept in ecological system can be traced from the word "eco" in ecology, by Isshiki as quoted by Astuti (2012), which comes from the Greek Oikos, means home for all; women and men, animals, plants, water, soil, air, and sun. So, in this case, Ecology studies the relationship between humans and the environment. Hence, it needs the linkages between the natural sciences and the human sciences interdisciplinary. Ecological awareness sees the reality of this world holistically integral, in which the world contains a lot of diversity and posseses interdependent networks that by Capra (2001) referred to the web of life.

In gender studies, issues of parenting, lately, becomes increasingly prominence as the outbreak of child abuse in different shapes and patterns that occur in the society, school and in the family as a social unit. Considering that gender relation is formed within families, the roles of public and domestic transactions are oftenly constructed by the socialization process in an environment (T. Ihromi, 1999: vii-viii). In the family itself, transfer of values intensively occurs that results in the character and identity of Indonesian children.

Therefore, family is the smallest human social environment in which its existence cannot be separated from home. The home is the most familiar human environment in domestic realm. It stimulates main ideas of culture which is produced and reproduced to form a system of meaning. In seeing the construction of meaning at home, the symbolically institutionalized arrangement in the house must always be read over and over in conjunction with the dwelling itself. The symbolic power of house is not attached in its isolated entities, but the relationships between the house and the surrounding resident.

House is also the main place for generative scheme of culture objectification, so it contains the vision and structure of society in the social context (Harker; Mahar, and Wilkes [ed], 2004: 8-7). The residents have a certain message to convey. Then, house is a social space, groups of characterized status which is characterized by various lifestyles (Haryatmoko, 2003: 8-9). The contention over symbolic perception of the social world takes two different perspectives; the objective and the subjective. On the objective side, people can act through representation, both individually and socially, in order to control the various particular view of reality. On the subjective side, people can act in a way to use self-presentation strategy or by changing the categories of perception and appreciation of the social world.

Both of these trends, by Bourdieu (1984: 143), is called with practical logic. which is always associated with symbols and has a stimulating source. That source which stimulate action, thought and representation is referred to habitus; an interpretive framework for understanding and assessing the reality as well as a producer of the practices of life in a dialectic of two reciprocal motion; First, the objective structure that is internalized in thought; second, a subjective motion which unveils the results the thought (Bourdieu 1990: 52; Haryatmoko 2003: 8-9). In the meantime, the concept of habitus cannot be separated from the realm of champ insocial field that is similar to the "free market" so that there are producers and consumers at the same time. Then, the society goes to maintain and improve their position, differentiate themselves to gain new 
positions so that the social struggles in the symbolic realm cannot be ignored (Rusdiarti, 2003: 31-40; Bourdieu, 1990: 112).

The existence of Javanese traditional house (read: Kudus traditional house) is one representation of the symbolic battles in the negotiation process (dialogue) between cultures that occurred back in the day. At least, elements of Javanese, Gujarat, Persian, Chinese and colonial are reflected in the various trappings of the traditional house with various symbolic backgrounds. This is partly reflected through the ropes, crown, and the number of fabulous animals sculpture (Said, 2012: 7; Triyanto, 2001; Said, 2011).

Kudus, with its Muslim majority, always put their nature wherever it is. For instance, in their social life; including the moral education in gender relations for their children as a social bond that is manifested in various aspects, which is also manifested in the house that are loaded with the values of ecological wisdom.

\subsection{House as a spiritual dan cultural capital}

Every city has typical and distinctive self-image because each possesses history and root of different cultures. Likewise with Kudus in Central Java. Besides known as "Kota Kretek", it is also popular with the name of "Kota Gebyok", which is well-known with its unique and aesthetic sculpture. "Gebyok" is a barrier or insulation between the living room (jogo satru) and family room in a traditional house of the most unique and has high artistic value. The unique sculpture ornaments in gebyok are very prominent and become a symbol of luxury. Let alone, the sculptures carved in gebyok is the result of acculturation of three cultures; Muslim, Persian and Chinese (Said, 2010: 65-66).

Gebyok has a corellation with the history of da'wah and the development of sculpture in Kudus. Sculpture in Kudus had been initiated since the entry of an immigrant from China named The Ling Sing around the 15th century. He is a Chinese scholar and had a strong preaching mission along his journey as an adventurer. At that time, his coming in Kudus turned out not only for the sake of da'wah, spreading Islam in Kudus and the surroundings, but also to his skill as an expert craftsmen (Said, 2010: 245).

Kyai Telingsing as a messenger with his feature and as a sculpture pioneer in Kudus was famous. Therefore, his moral values are considerably noted by the Moslems in Kudus. Some of the popular sayings of Kyai Telingsing is: "Sholat Sacolo Saloho sampurna Donga", which means: Sholat is a perfect prayer; Lenggahing panggenan Tersetihing Ngaji, means: Put yourself in something true, holy and honorable (Mufid, 1985; Said, 2012: 30-31). Kyai Telingsing messages reflects how much he cares Kyai Telingsing about the importance of establishing honesty and purity as the core values in building a noble character, which can only be accomplished by carrying sholat (khusu ') as the best of how to pray.

In a story, Kyai Telingsing was told as a top calligraphy artist who is widely acknowledged in Kudus. In addition to his famous calligraphy, Kyai Telingsing is also known as a Sun Ging sculptor. From the word of "Sun Ging", the word "Nyungging" formed, which means to sculpt or to carve, and from that word, the place where he lived, then, is called as Sungingan Village where He rests for good. (Mufid, 1985; Said, 2012: 31-32). Every Thursday and Friday, His grave are visited by numerous pilgrims from different backgrounds; the Javanese, the Chinese and the surroundings as well.

Another version says that in the period Kyai Telingsing there was also a prominent Chinese craftsman named Sun Ging An who assisted Kyai Telingsing in expanding the art of sculpture. His sculpture is distinctively known and has its own character. The people calls it Sun Ging sculpture, which is acknowledged with its subtlety 
and beauty, yet intricate as seen in a variety of carved ornaments in Kudus traditional house (Suptandar, 2001; Said, 2012: 33).

Many of the apprentices of Kyai Telingsing did not only learn about Islamic sciences but also the sculpture in Kudus. Kudus sculpture that flourished focused more on the shape of home ornaments that became known as the traditional house of Kudus, unlike Jepara, in which the sculpture is tend to be more on meeting the needs of households and equipment such as cabinets, tables, chairs, decorations, and the like. Therefore, Jepara is more popular with the name of City of Carving, due to its more manifold products and the widely spread of carving culture.

Nevertheless, Kudus sculpture with its flagship product; Kudus traditional house, has a distinctive feature for the actualization of art as a medium for carving is more to the symbol of the residents, so it is not just for commercial purposes, as happened in Jepara. It serves as a unique and philosophic place for living in to dwell concept which represents the character of the residents (Soekotjo, et al. [Eds.], 2008: 41; Said, 2012: 34).

It can be said that, in its history, Kudus traditional house cannot be separated from the owners' expression of consciousness to actualize ideas, perspectives and way of life, especially in Kudus Kulon (West Kudus). Around the 18th century, Kudus traditional house made its heyday, in the midst of Dutch colonization. Almost every parts of houses was filled with unique and enchanting carvings. However, a simpler traditional house, but lack on the obtrusive carving had emerged around the 16th century.

The construction is made completely in knock down system, to enable the ornament of each part worked in detail and full of complexity, as well as allowing the possibility for relocation can be done easily.

The ownership of various types of traditional house is in the accordance to the owner's financial status. The more prominent the ornament is, the more value it has, both artistically and financially. This showed the level of economic development of the society at that time, or, at least, the residents. Therefore, among the people of Kudus Kulon who managed their business, used to actualize their success by owning the traditional house as a marker of high dignity along with social generosity as the "spirit of santri" (Said, 2012: 39).

Socially, the status of Kudus people were generally categorized as the coastal whose standard of living is much more economically advanced when compared to the nobility and gentry / employee (Thohir, 2006: 29). Sadly, in everyday life they received lack appreciation and respect from the community, particularly by the Dutch. Livelihood as merchants was considered as low end yet not honored. Then, the people of Kudus Kulon, whose majority were merchants, pulled off a counter culture through their royal house with fancy ornaments. The hight of floor was terraced to suit the social strata as was done by a group of nobles. The wall around the house were also made the same as the shape of a palace (Said, 2012: 40).

The resistance by people in Kudus Kulon against colonial domination in this case can be regarded as a symbolic resistance, a non-violent resistance but by presenting a cultural sign that stores the signifier and the signified (Barthes, 1967). The signifier is the material manifestation of the traditional house with a variety of unique ornaments, fancy carvings as well as by a high fence surrounding it like a palace. While the signified is the spirit of resistance that indigenous groups also have self-esteem and dignity that deserves to be taken into account in dealing with colonial groups that actually had taken away the country's resources. 


\subsection{Parental communication patterns in the house construction}

Home is the first and the main source of learning. The parents take the role as a teacher while the environment they live is the book. At home, either the process of socialization in thinking, feeling and behaving is intensively carried out that consequently forms a character (Soe'oed, 1999: 30-32). Socialization, in this case, can be seen as a learning process experienced by someone (read: kids) to obtain knowledge, values and norms so that he can participate as a member in a certain group of people (Goslin in Soe'oed, 1999: 30- 32).

The process of an individual becoming a social being can be influenced by many factors including: heredity or nature and environment or nurture (Goslin in Soe'oed, 1999: 30-32). So, social interaction is an important element in the socialization, through the family and parents at home or family as the main agent of socialization for children character building in a family.

In consequence, conditioning the social and the physical environment is like two sides of a coin. Both strengthen the resilience of a child character in the family and society. For this sake, it is interesting to understand the construction of Kudus traditional house as a cultural heritage which can be analyzed in the perspective of parenting by identifying the various systems of meaning in every cultural sign laid behind the ornament and spatial layout of the house. The keyword in character education is the need for a harmonious relationship in the family, both physically and socially, since it serves as role model so that the process of modeling in social education of the children always keeps on progressing.

To that extent, it can be understood that the harmonic structure of Kudus traditional house can be found in the following:

\subsubsection{Harmonious communication in God relations}

Regarding to the relation with God, it is clearly shown in the bottom of the traditional house which functions as the base that sustains the whole building consisting of 5 traps on the ground as a symbol of Islam's vision; the five pillars of Islam (Said, 2012: 39). In jogo satru (living room) there is a pole-called Soko Geder, which functions as the roof prop and symbolize the Oneness of Allah (Tawheed). It also serves as a reminder, for both men and women living in the house, to always puts faith and taqwa in Him, even it is joy or sorrow. In addition, Soko Geder worth a sign of guidance of life; The Almighty, for the residents of the house. (Said, 2012: 59).

Here, the existence of five trap and Soko Geder provide a strong foundation in the vision of life in to dwell concept. In moral education, Islamic value is strongly emphasized. In this case, the values of Tawheed (symbolized by Soko Geder) and the five pillars of Islam which are symbolized by the five traps clearly become the core values upheld by the residents.

Not merely to understand the essence of the pillars of Islam, but at the same time to carry them out in the family, start from the implementation in house construction. The practice of carrying out the 5 pillars of Islam is what the reviewers of residential culture theory refer to the 'cultural apprenticeship', which is a process of learning by doing, applying Islam in a room in the family's life.

\subsubsection{Harmonious communication in human relations}


The values of environmental harmony in the attempt to form self authenticity and social relationships can be observed in the presence of "gedongan" (jogan lebet); a structural frames propped solidly by 4 pillars (sokoguru). The four pillars symbolize how to be a well-mannered person, for man and woman, who can control themselves from "napsu patang perkoro" (four desires of the cause) namely; amarah, luamah, sufiah, and mutmainnah. Amarah is a desire which drives people to act of evil, luamah always push people to live excessively, wastefully and materialistically. Sufiah urges people to live a simple life with the spirit of spirituality that makes the material as a medium for devotion and faith to the Almighty. It does not make the material as the goal of life, but only a supporting achievement towards His way. Muthmainnah is the human impulse toward peace of mind even at a certain level material affairs are becoming obsolete, there is only the desire to "merge" with Him (Said, 2012: 60-61; Suptandar, 2001).

Meanwhile, the existence of pengeret tumpang pitu in joglo symbolizes that the birth of human to the world is not alone by himself, but along with kadang pitu (the Sibling Seven ); mar, marti, kakang kawah, adi ari-ari, getih (blood), puser and pancer sukma (spirit). Therefore, the family should be able to unite all of its member as to create a harmony which is mutually beneficial to the happiness of living in the world and the hereafter (Said, 2012: 63).

Proceeds, as a manifestation of personality represented by the residents is found in "Joglo Pencu", neat and nice, mighty firm and graceful. It represents the role figure of the residents; (a) firm and principled, not easily affected by the current; (b) mighty, not easily subjugated by any group including the colonial, so that the dignity is wellmaintained, (c) gracefull, in the sense of how the residents also pay attention to aesthetic values in interacting with others.

The values of firmness, strength / commitments and elegance as contained in the symbolic meaning of Kudus traditional house are universal values that can be internalized as moral foundation for both women and men. However, it requires the joint efforts of husband, wife and children in a family that later became a dignified family that led to the strengthening of the nation's dignity.

\subsubsection{Harmonious communication in natural environment relations}

Harmonious relation with the nature in Kudus traditional house is representated through Pakiwan. Pakiwan is a place to cleanse from all "dirt" both physically and spiritually in order to avoid any disruption of both, physically and mentally. Hence, Pakiwan in Kudus traditional house is intended as a place of cleansing ourselves of all evil, unjust, and other disorders that cause various illness.

Each person when entering the house should be in a state of purity from all dirt. Pakiwan is always placed outside, in front of the left side of house, in line to the kitchen. It is attended to prevent any kind of disorder and filth everytime the residents enter the house, through the process of "self-purification" beforehand.

Which belongs to pakiwan is well, bathroom, toilet and padasan (place for ablution). Well, shower and toilet are means for cleansing the physical dirt, while padasan and bathroom also serves as a means of cleaning the dirt off of the inward (hadas). Beside for the sake of personal hygiene, why the pakiwan is always outside the home is a strategy to maintain the water hygiene, healthy, and free from any harmful virus (Said, 2012: 7172; Said, 2011: 195-200).

Some of the description above show that parenting, as a process of character education, requires the dimensions of conditioning and modeling or in the theory of 
character education is oftenly called the aspects of feeling and acting the good which play more dominant eoles rather than the aspect of knowing the good, and Kudus traditional house has fully represented it all.

Let alone, the moral values put forward in the process of social interaction in parenting is very prominent in the construction of the traditional house. It can be observed through the importance of three harmonious relationships in parenting that is in relationship with God, fellow human beings and the environment, including animals, plants and nature.

It means that any individual who intends to establish a house should be ready to make the house as a medium of parenting through the process of socialization and social interaction in the process of cultural apprenticeship thereby a harmonious relationships in touch with God, man and nature are formed.

So, no wonder that in Javanese tradition, everytime held "slametan" or "bancakan" (Javanese feast) there is always what is known as "tumpeng", ie, yellow rice forms a sort of mound triangle in which each angle described three entities built in harmony. Again, it also reflects the importance of harmony in relationship with God, human and nature as the message of ethics and esthetics in Kudus traditional Javanese house, Central Java.

Therefore, ideal parenting needs to begin at home (family), and what RA Karitini (through her letters compiled in the Out of Darkness to Light), as a reminder for the currentand the future generation:

"... I am so grateful if you are willing to put concern on women education. It is not because we want to make women turn into rivals for men in the struggle of life. We want to make women being more proficient in carrying out the great task placed by the Mother Nature, in order to become major educator for mankind! "(Letter to Prof. and Mrs. GK Anton, October 4, 1902).

What lies within RA Kartini is a product of parenting in a family of Javanese traditional house as well as Kudus traditional house. If Jepara, Kartini's hometown ,is wellknown as the city of carving, but specifically, gebyok carving is very popularly belongs to Kudus, which subsequently became known as Kudus traditional house where the Mother of RA Kartini, Nyai Ngasirah, also buried in Kaliputu Graveyard Kudus, Central Java; an area where there are a number of the traditional house.

Women emancipation which Kartini fought for is an emancipation that still maintains family harmony including in parenting role in the family, or borrowing a phrase from Kartini, to remain as "Mother Nature," as the primary educator of mankind, especially in the family. Then, gender movement in Indonesia should also have the distinction that is in consonance with the cultural wisdom of the the nation. In this circumstance, parenting wisdom in the construction of Kudus traditional house as the national heritage becomes very important to note by Indonesian gender activists and generation, in order to avoid blunder in gender movement. 


\section{Conclusion}

The above discussion, it can be concluded that the occurrence of various violence and sexual abuse of children could not be separated from the influence of social institutions that developed in various social unit for a means of socialization and healthy social interaction based on ecological justice. That effort could be done through the strengthening of social institutions in the family (home).

The house is the most familiar human environment in the domestic sphere since there are major cultural ideas produced and reproduced to form a system of meaning. Hence, the existence of Kudus traditional house with its ornaments and spatial system, wrapped in a system of meaning on its existence reflects the moral values of life which must be actualized and implemented. Then, to dwell in this case is as a cultural apprenticeship in building harmonious dignified dwelling and parenting system with God, fellow human beings and nature.

Parenting system in Kudus traditional house is reflected the ecological justice in the meaning of spatial networks, ornaments and spatial construction. Therefore, behind the physical existence of the traditional house lies the spirit of cultural apprenticeship that can be used as an alternative reference of best practices in designing parenting pattern through character education within the family at home.

The implication for feminist movement activists is that the gender justice movement in Indonesia needs to have a distinction that is in harmony with the national cultural wisdom. Because it is necessary every gender activist in Indonesia has cultural awareness and cultural intelligence in designing the gender justice movement. Included in this case can take lessons from child-friendly family education patterns in ecological justice in traditional Javanese homes.

\section{References}

[1] Astuti, T.M.P., "Ekofeminisme dan Peran Perempuan dalam Lingkungan", dalam Indonesian Journal of Conservation, Vol. 1 No. 1 - Juni (2012).

[2] Baker, C., Cultural Studies, Teori dan Praktek, Yogyakarta: Kreasi Wacana, Cet.II, 2005.

[3] Barthes, R., Elements of Semiology. London: Jonathan Cape. (1967).

[4] Bourdieu, P., Distinction, A Social Critique of the Judgement of Taste. Terj. Richard Nice. New York and London: Routledge, (1984).

[5] Bourdieu, P., The Logic of Practice. Terj. R. Nice, Stanford: Stanford University Press. (1990).

[6] Capra, F., Jaring-jaring Kehidupan, Visi Baru Epestemologi dan Kehidupan. Yogyakarta: Fajar Pustaka Baru. (2001).

[7] Darwin, M.D. "Reorientasi Kebijakan Pendidikan yang Adil dan Setara", Hand-out disampaikan pada "Temu Pimpinan dan Pelatihan Pengarusutamaan Gender Bidang Pendidikan di 16 PTN dan PTS di Jawa Tengah serta Dinas Pendidikan Kabupaten Wonosobo dan Grobogan". Hotel Asia, Surakarta, 20-21 November (2013).

[8] Eco, U., Social Life as a Sign System. Oxford: Clarendon Press. (1979).

[9] Geertz, C.. The Interpretation of Culture. New York: Basic Books. (1973).

[10] Hall, E.T. A System for the Notation of Proxemic Behavior, dalam American Anthropologist, Volume 65, Issue 5, Oktober (1963), pp. 1001-1217 
[11] Harker; Mahar dan Wilkes. Pengantar Paling Komprehensif Kepada Pemikiran Pierre Bourdieu. Yogyakarta: Jalasutra. (2004).

[12] Haryatmoko. "Menyingkap Kepalsuan Budaya Penguasa", dalam Basis No.11-12 ke-52, NovemberDesember. (2003).

[13] Ihrom, T.O., Bunga Rampai Sosiologi Keluarga, Jakarta: Yayasan Obor Indonesia, (1999).

[14] Mufid, H. Zawawi, "Sekelumit Sejarah Mbah Kyai Telingsing", Dokumen Ketika Yayasan Pendidikan Kyai Telingsing Kudus. (1985).

[15) Pramesti, Olivia Lewi. Potret Lingkungan Indonesia Kian Memprihatinkan; Kasus eksploitasi lingkungan semakin banyak dan tidak sedikit yang mengalami kerusakan", dalam http://nationalgeographic.co.id/berita/2012/10/potret-lingkungan-indonesia-kianmemprihatinkan (diakses 1 Nopember 2013).

[16] Soe'oed, R. D., "Proses Sosialisasi", dalam Ihrom, T.O., Bunga Rampai Sosiologi Keluarga, Jakarta: Yayasan Obor Indonesia, 1999.

[17] Rusdiarti, Suma Riela. "Bahasa, Pertarungan Simbolik dan Kekuasaan”, dalam Basis No.11-12 ke52, November-Desember (2003)

[18] Said, N. Tradisi Pendidikan Karakter dalam Keluarga, Tafsir Sosial Rumah Adat Kudus. (Edisi Revisi). Kudus: Brillian Media Utama. (2012).

[19] Said, N. "Budaya Berhuni Kaum Sufistik Borjuis, Kontestasi Simbolik Dalam Konstruksi Rumah Adat Kudus", dalam Jurnal eL-Harokah Vol.12/3 (239-260). (2010).

[20] Said, N. "Nilai-nilai Pendidikan Akhlak dalam Rumah Adat Kudus", dalam Jurnal Penelitian Pendidikan Islam EDUKASIA, Vol. 8, No. 2, Juli-Desember (2011).

[21] Said, N. etc, "Child friendly family education in Indoensia - Javanese Traditional House Construction" presented in 8th Bangkok International Conference on Language, Education, Business, and Law (LEBL-17), Dec. 25-26, (2017).

[22] Schulz, C.N. The Concept of Dwelling: On the Way to Figurative Architecture. New York: Rozolli. (1985).

[23] Tjahjono, G. "Pengantar", dalam, Revianto Budi Santoso. Omah; Membaca Makna Rumah Jawa, Yogyakarta: Bentang Budaya, (2000).

[24] Soekotjo, dkk. Peninggalan Sejarah dan Purbakala Kabupaten Kudus. Kudus: Dinas Pariwisata dan Kebudayaan Kabupaten Kudus. (2008).

[25] Suptandar, J.P. "Arsitektur Rumah Adat di Kudus untuk Dakwah, Seni, dan Martabat”, dalam KOMPAS, 2 September (2001)

[26] Shiva, V. Bebas dari Pembangunan,Perempuan, Ekologi dan Perjuangan Hidup di India, Penerjemah; Hira Jhamtani, Jakarta: Yayasan Obor Indonesia. (1997).

[27] Thohir, M. Orang Islam Jawa Pesisiran, Semarang: Fasindo Press, (2006).

[28] Triyanto. Makna Ruang \& Penataannya dalam Arsitektur Rumah Kudus. Semarang: Kelompok Studi Mekar, 2001. 